\title{
PGD-ens paradokser
}

\section{Bjorn Hofmann}

Bakgrunn: Preimplantasjonsgenetisk diagnostikk (PGD) er en genetisk undersøkelse av befruktede egg før de settes inn i livmoren i forbindelse med assistert reproduksjon. Hensikten med PGD er å unngå at det fremtidige barnet får en alvorlig arvelig sykdom, og at par som på grunn av arvelig sykdom har vansker med å få barn, kan få avkom. PGD er kontroversielt og et sentralt tema for den pågående vurderingen og revisjonen av bioteknologiloven.

Metode: Paradoksteori anvendes for å identifisere og analysere noen av kontroversene ved PGD. Det skilles mellom tilsynelatende paradokser, antinomier og aporier. Materialet er offentlige dokumenter, debattinnlegg og faglitteratur. Resultater: Det finnes en rekke tilsynelatende paradokser på PGD-ens område, slik som at PGD gjøres selv om det er svort liten sannsynlighet for at det blir født et alvorlig sykt barn, og at det gjøres PGD for mindre alvorlige sykdommer når forutsetningen for PGD er alvorlig arvelig sykdom. Samtidig finnes det også antinomier: At PGD gir rett til helsehjelp uten at det eksisterer noen pasient, og at PGD gjennomføres selv ved høye kostnader og lav suksessrate. Om embryoet og fosteret har moralsk status og rett på beskyttelse, synes å utgjøre en apori.

Konklusjon: $\AA$ formulere moralske utfordringer som paradokser kan vore en fruktbar måte å tydeliggjøre utfordringer og motsetninger på. Dessuten kan det styre innsatsen: Vi bør bestrebe oss på å rydde opp i tilsynelatende paradokser, jobbe hardere med grunnlagsutfordringene ved antinomier og til en viss grad akseptere motsetningene ved aporiene.

Nøkkelord: Preimplantasjonsgenetisk diagnostikk, paradoks, antinomi, apori
Bjorn Hofmann, Universitetet i Oslo/ Høgskolen i Gjøvik, b.m.hofmann@ medisin.uio.no/ bjoern.hofmann@hig.no 


\section{English summary: PGD's Paradoxes}

Background: Pre-implantation genetic diagnosis (PGD) is a genetic test of embryos before implantation as part of in vitro fertilization. The purpose of using PGD is to help people avoid having children with serious genetic disease and to help those with genetically based infertility to have children. PGD has been controversial and is assessed as part of the revision of the Norwegian biotechnology act.

Method: Paradox theory is used to identify and analyse controversies with PGD. It distinguishes between resolvable paradoxes, antinomies and aporias. The material comprises official documents, public debates, and professional publications.

Results: Many resolvable paradoxes are identified with PGD, such as that $P G D$ is done even in cases where there is very little chance that a seriously ill child will be born and in case of diseases that are not considered to be «serious inheritable disease," as required by the law. At the same time, there are antinomies: PGD is subsumed within a patient's rights even if there is no patient, and PGD is done even when the success rate is low and the expenses are high. Whether the embryo and the foetus have a right to protection appears to be an aporia.

Conclusion: Analysing moral problems in terms of paradoxes may be a fruitful way of displaying challenges and conflicts. Moreover, it may give focus and direction to our endeavours. That is, we should try to resolve the resolvable paradoxes and work harder with the conflicts of the antinomies, and, to a certain extent, to accept the antagonisms of the aporias.

Keywords: PGD, paradox, antinomy, aporia, infertility, genetic disease, ethics

\section{Innledning}

5. desember 2003 vedtok Stortinget bioteknologiloven (Lov nr. 100 om humanmedisinsk bruk av bioteknologi m.m.). Denne loven tillot bare genetiske undersøkelser av embryo ved alvorlig kjønnsbundet sykdom, og det var ikke tillatt med hjelpesøsken. ${ }^{1}$ Tre måneder senere, 28. februar 2004, hadde TV 2 en nyhetssak om seks år gamle Mehmet som ville komme til å dø fordi han ikke kunne få benmarg fra et søsken på grunn av den restriktive bioteknologiloven i Norge. Saken skapte en voldsom debatt og førte til at bioteknologiloven ble endret med virkning fra 1. september samme år. Med Mehmet-saken gikk Norge fra å ha «verdens strengeste bioteknologilov» (Hafstad 2004; Haug 2005; Haug C 2006; Haug K 2006; Bjørvik 2009; Hofmann 2004) til å få en «liberal lov», sett med samtidens øyne. 
I ettertid virker det paradoksalt at det som man noen måneder tidligere hadde vært enige om, skulle skape så stor uenighet ut fra et kort nyhetsoppslag. Det synes også paradoksalt at en konkret sak, som man kjente tilsvarende eksempler på fra andre land, var det som skulle til for å endre loven. Videre virker det som et paradoks at det som alle hadde oppfattet som det mest kontroversielle, «fremstilling av hjelpesøsken», var det som skulle etablere en praksis med genetisk testing av befruktede egg for alvorlig arvelig sykdom. Det er også overraskende at politikere som deltok aktivt i beslutningen, i ettertid ga uttrykk for at de ikke vedkjente seg eller forsto rekkevidden av beslutningen. Journalister, som i vesentlig grad bidro til å holde saken på dagsordenen og presset på politikerne oppe, erkjente at de misforsto og misbrukte sin rolle (Folge 2006). Hvordan var dette mulig?

En av forklaringene er at innføringen av PGD i Norge inneholdt en rekke motsetninger. Hensikten med denne artikkelen er å granske disse som paradokser. Målet er å skille tilsynelatende paradokser fra mer grunnleggende former for motsetninger, slik som antinomier og aporier. Det kan forhåpentligvis bidra til en mer oversiktlig og nyansert debatt i forbindelse med vurdering og revisjon av bioteknologiloven (Helsedirektoratet 2010).

\section{Materiale og metode}

Artikkelen benytter offentlige dokumenter som lovforarbeider og rapporter om assistert reproduksjon som grunnlag for analysen. Den bruker den aktuelle debatten for å illustrere paradoksene og støtter seg på faglitteraturen for å belyse dem.

Paradoks kommer fra gresk, para-doxa, som betyr «motsatt mening». Opprinnelig ble para-doxa brukt om det som gikk mot alminnelig oppfatning og tro. Senere har betegnelsen fått en videre betydning, og den brukes om alle de tre betydningene som er brukt i denne artikkelen. Felles for disse er at paradokser er relatert til ulike former for motsetninger.

Analysen følger en metodikk som skiller mellom tilsynelatende paradokser, antinomier og aporier og er beskrevet i detalj i Hofmann (2002). Tilsynelatende paradokser forstås som tilsynelatende selvmotsigende påstander som ved nærmere undersøkelse lar seg oppløse eller løse. Antinomier er motsetninger som oppstår mellom to motstående prinsipper og verdier eller gyldige slutninger fra slike prinsipper og verdier. Antinomier involverer mer grunnleggende motsetninger, og de er vanskeligere å løse. De skiller seg fra løsbare paradokser både i struktur og i utfordring, men det kan være mulig å løse dem, for eksempel gjennom nye begreper, perspektiver, teorier eller prinsipper. ${ }^{2}$ 
Aporier er situasjoner der grunnleggende prinsipper står mot hverandre, og hvor vi ikke kan se noen utvei eller løsning. Dette gir et teoretisk rammeverk som er gjengitt i tabell 1 .

Tabell 1: Oppsummering av det metodiske rammeverket for strukturering av analysen $i$ artikkelen

\begin{tabular}{|c|c|}
\hline Type paradoks & Hva paradokset består av \\
\hline $\begin{array}{l}\text { 1. Tilsynelatende paradoks } \\
\text { a. Språklige uklarheter } \\
\text { b. Uuttalt avveiing av ulike } \\
\text { hensyn } \\
\text { c. Ulik behandling av tilsynela- } \\
\text { tende like tilfeller } \\
\text { d. Mangelfull argumentasjon }\end{array}$ & $\begin{array}{l}\text { Tilsynelatende selvmotsigende på- } \\
\text { stander, som ved nærmere under- } \\
\text { søkelse lar seg oppløse eller løse } \\
\text { gjennom forklaringer eller argu- } \\
\text { menter. }\end{array}$ \\
\hline 2. Antinomi & $\begin{array}{l}\text { Motsetningen mellom to motståen- } \\
\text { de prinsipper og verdier eller gyldi- } \\
\text { ge slutninger fra slike prinsipper og } \\
\text { verdier. }\end{array}$ \\
\hline 3. Apori & $\begin{array}{l}\text { Sterke motstående prinsipper der } \\
\text { en utvei eller løsning synes fjern el- } \\
\text { ler umulig. }\end{array}$ \\
\hline
\end{tabular}

Det som er typisk for paradokser, er at de er overraskende og tankevekkende. Derfor kan paradoksene ved vurdering og innføring av ny bioteknologi kanskje lære oss noe vesentlig om hva det vil si å være et menneske i en teknologisk tidsalder: Vi må håndtere og leve med en rekke motsetninger. For en nærmere beskrivelse av metoden, referanser og eksempler, se Hofmann (2002).

Paradoksanalyser egner seg best for å belyse og nyansere komplekse situasjoner. De er uegnet for ekstreme normative posisjoner, som for eksempel ytterliggående deontologi eller utilitarisme, fordi det her nærmest ikke finnes paradokser: PGD er enten nærmest alltid galt fordi det innebærer seleksjon og destruksjon av (potensielle) personer, eller PGD er nesten alltid rett fordi verdien av å frembringe et nytt (friskt) menneske er svært stor. 


\section{Hva er PGD?}

Preimplantasjonsgenetisk diagnostikk $(\mathrm{PGD})^{3}$ er betegnelsen på en genetisk undersøkelse av befruktede egg før de settes inn i livmoren. PGD gjøres i forbindelse med befruktning utenfor livmoren, invitrofertilisering (IVF), som er en av flere former for assistert befruktning. PGD gjøres ved at enkeltceller tas ut når det befruktede egget har delt seg i 8-10 celler (Bioteknologinemnda 2010). Cellen som tas ut, analyseres med ulike metoder for å kartlegge bestemte molekylærbiologiske egenskaper.

Hensikten med PGD er å velge bestemte egenskaper for det fremtidige barnet. I Norge er PGD grunnlag for fravalg og tilvalg (Solberg 2005). Tre egenskaper åpner for valg: a) alvorlig arvelig sykdom, b) embryoets HLAtype (humane leukocytt-antigen) og c) kjønn. I det første tilfellet (a) bortvelges embryoer som har molekylærbiologiske egenskaper som er assosiert med alvorlige arvelige sykdommer, for å unngå at det kommende barnet får slik sykdom. Embryoet kan også velges for implantering (tilvalg) ut fra om det har bestemte HLA-egenskaper som er assosiert med vevsforlikelighet til et allerede eksisterende sykt barn som man ønsker å hjelpe (b). Kjønn kan velges (c) dersom det er risiko for at barnet vil få en alvorlig kjønnsbundet sykdom. Det kan være vanskelig å skille tilvalg og fravalg (Glover 1984), og tabell 2 oppsummerer valg og egenskaper. Tilvalg ved HLA-typing kan gjøres uavhengig av fravalg ved PGD og er tillatt i andre land, men ikke i Norge. Ved kjønnsseleksjon på grunn av alvorlig arvelig sykdom gjøres det tilvalg av ett sett kjønnskromosomer (XX) og fravalg av et annet sett kjønnskromosomer (XY).

Tabell 2: Valgformer og egenskaper ved PGD $i$ Norge

\begin{tabular}{|l|c|c|c|}
\hline & $\begin{array}{c}\text { Alvorlig arvelig } \\
\text { sykdom }\end{array}$ & HLA-type & Kjønn \\
\hline Tilvalg & & $\mathrm{X}$ & Kjønn 1 \\
\hline Fravalg & $\mathrm{X}$ & & Kjønn 2 \\
\hline
\end{tabular}

\section{PGD i Norge}

I Norge tillates PGD dersom det er en alvorlig og arvelig sykdom i familien, og det er stor fare for at et fremtidig barn arver sykdommen, og der årsaken til sykdommen i familien er kjent. Genfeilen/kromosomfeilen må være kartlagt, og det må være mulig å etablere en metode for å undersøke om embryoet arvet sykdommen (genetisk diagnostikk). Paret må også egne seg til assistert befruktning (medisinsk og psykososial vurdering), det må være bosatt i Norge, og kvinnen må ikke allerede være gravid. Det stilles også krav om kostnadseffektivitet. 
PGD tillates i Norge ved a) påvist monogen alvorlig arvelig sykdom, b) påvist alvorlig kromosomanomali, det vil si balanserte kromosomfeil og andre strukturelle kromosomfeil, og c) ved behov for hjelpesøsken. Ved hjelpesøsken (PGD + HLA) stilles det i tillegg krav om at det syke barnet med stor sannsynlighet vil kunne kureres, at hensynet til det syke barnet må veies opp mot belastningene for det fremtidige barnet (med å være donor), og at det nye barnet ikke må utsettes for unødig belastning eller uakseptable inngrep.

Ei egen nemnd (PGD-nemnda) vurderer om vilkårene i loven er oppfylt. PGD har til nå foregått i utlandet, i hovedsak i Sverige og Belgia. Tabell 3 viser omfanget av behandlede saker.

Tabell 3: Søknader behandlet i PGD-nemnda fra 2004-2010. Tallene er hentet fra PGD-nemndas nettsider

\begin{tabular}{|l|c|c|c|}
\hline År & Innvilget & Avslått & Avvist \\
\hline $\mathbf{2 0 0 4}$ & 1 & 0 & 0 \\
\hline $\mathbf{2 0 0 5}$ & 19 & 0 & 1 \\
\hline $\mathbf{2 0 0 6}$ & 21 & 1 & 3 \\
\hline $\mathbf{2 0 0 7}$ & 17 & 2 & 1 \\
\hline $\mathbf{2 0 0 8}$ & 22 & 3 & 0 \\
\hline $\mathbf{2 0 0 9}$ & 17 & 3 & 0 \\
\hline $\mathbf{2 0 1 0}$ & 24 & 1 & 0 \\
\hline Sum & 121 & 10 & 5 \\
\hline
\end{tabular}

\section{Hvilke tilstander tillater til- og fravalg? Hva regnes som alvorlig} arvelig sykdom?

Tabell 4 viser en oversikt over de sykdommene der det er gjort henholdsvis PGD og PGD med HLA-typing i Norge. 
Tabell 4: Oversikt over de sykdommene der PGD-nemnda har innvilget PGD alene, og der PGD er innvilget sammen med HLA-typing. I tillegg er det giort PGD for kjønnsbundne sykdommer i Norge, slik som Blue Cone monochromasi, der nemndsbehandling tidligere ikke var nødvendig. Tabellen baserer seg på informasjon fra www.klagenemnda.no. Fra 2008 er ulike sjeldne sykdommer gruppert sammen under «sjeldne sykdommer». PGD og PGD + HLA kan derfor voere innvilget for andre sykdommer enn dem som er nevnt i tabellen

\begin{tabular}{|l|l|}
\hline $\begin{array}{l}\text { Sykdommer der det er innvilget } \\
\text { PGD alene }\end{array}$ & $\begin{array}{l}\text { Sykdommer der det er innvilget } \\
\text { PGD + HLA }\end{array}$ \\
\hline Alpers syndrom & Beta-thalassemi \\
\hline Cystisk fibrose & Høyeraal-Hreidarson syndrom \\
\hline Duchennes muskeldystrofi & Wiskott-Alsrichs syndrom \\
\hline Dystrofia myotonika & \\
\hline $\begin{array}{l}\text { EEC, splitt hånd/splitt fot mal- } \\
\text { formasjon }\end{array}$ & \\
\hline Fragilt X-syndrom & \\
\hline Frontometafyseal dysplasi & \\
\hline Hemofili A & \\
\hline Huntingtons sykdom & \\
\hline $\begin{array}{l}\text { Karbohydratdefekt glykoprotein- } \\
\text { sykdom (CDG) }\end{array}$ & \\
\hline Kompleks I-defekt & \\
\hline Kromosomfeil & \\
\hline Nevrofibromatose & \\
\hline Osteogenesis imperfecta & \\
\hline Retinoblastom & \\
\hline Tuberkuløs sclerose & \\
\hline X-bundet hypofosfatemisk rakitt & \\
\hline X-bundet myotubulær myopati & \\
\hline
\end{tabular}

I andre land gjøres fravalg for andre sykdommer og tilvalg av andre egenskaper enn HLA-type. Eksempelvis rapporterte 5 prosent av 190 amerikanske PGD-klinikker at tilvalg av tilstander som døvhet og kortvoksthet (dvergvekst) ikke var uvanlig (Baruch et al. 2008). Tilsvarende rapporterte 42 prosent av de 190 amerikanske klinikkene at de hadde gjort ikke-medisinsk kjønnsseleksjon (Baruch 2008). 


\section{Paradokser}

Nedenfor følger en analyse av et lite utvalg paradokser. Paradoksene er valgt ut fra ønsket om å synliggjøre bredde og variasjon og for å vise kompleksiteten i de normative utfordringene ny bioteknologi reiser. Strukturen i presentasjonen følger det teoretiske rammeverket for paradokser (Tabell 1).

\section{Tilsynelatende paradokser relatert til språklige uklarheter}

Ett iøynefallende paradoks fremkommer i forarbeidene til dagens bioteknologilov (Ot.prp. nr. 26, 2006-2007), der PGD konsekvent omtales som «PGD-behandling». Dette skulle da i klartekst bli «preimplantasjonsdiagnostikk-behandling», noe som virker som en selvmotsigelse. I helsetjenesten gjør man enten diagnostikk, eller så gir man behandling, og diagnostikk-behandling lyder paradoksalt. ${ }^{4}$

Betegnelsen «PGD-behandling» har oppstått som følge av at PGD gjøres som et ledd i en behandling (IVF). Dette utgjør derfor et tilsynelatende paradoks som skyldes språklige uklarheter (type 1a). Paradokset ville forsvinne helt dersom man bruker «IVF-behandling og embryoseleksjon på bakgrunn av preimplantasjonsgenetisk diagnostikk», eller i kortform «IVF med PGD». Mens det for fagfolk ganske åpenbart er et tilsynelatende paradoks, kan det være forvirrende for lekfolk at man bruker betegnelsen «PGDbehandling». Parene som vurderer IVF med PGD, har mye å sette seg inn i, og uklar terminologi kan gjøre prosessen vanskeligere.

\section{Tilsynelatende paradokser relatert til uuttalte avveiinger}

Hensikten med PGD er å gjøre det mulig for par med anlegg for alvorlige arvelige sykdommer å få barn uten den arvelige sykdommen. Men hva er sykdom? Det sier loven ikke noe om, og dens taushet gir derved rom for paradokser. ${ }^{5}$ Eksempelvis er det å være bærer av en alvorlig arvelig sykdom i seg selv ikke en sykdom. Personen selv føler seg ikke syk og trenger ikke helsefaglig behandling. Dette går også frem av Ot.prp. nr. 26, der det åpnes for å sette inn «embryo med bærerstatus». Samtidig anbefaler departementet «at slike embryoer unngås så langt som mulig» (Ot.prp. nr. 26 (20062007): 52). Sykdommen som bærertilstanden kan lede til, regnes som alvorlig. Faren for å bringe sykdommen videre regnes også som stor, men risikoen er mindre alvorlig enn selve sykdommen. Det at bærertilstanden både regnes som («behandlingstrengede») sykdom (for å få et friskt barn) og som ikke-sykdom (uten symptomer) er derfor et resultat av bakenforliggende avveiinger.

Formålet med bioteknologiloven er at «medisinsk bruk av bioteknologi utnyttes til beste for mennesker $i$ et samfunn der det er plass til alle» (\$1-1). Da virker det paradoksalt at loven selv gjør mindre plass til personer med 
bærerstatus i fremtiden. At man skal unngå embryo med bærerstatus, gir inntrykk av at personer med bærerstatus er mindre verdt. Her kan paradokset (type 1b) forklares ut fra helsetjenestens ansvar: Dersom helsetjenesten intervenerer (i forhold som ellers skjer uten helsetjenestens involvering), vil det være ansvarlig for konsekvensen av intervensjonene. Her avveies mulig fremtidig uhelse hos et barn mot hensynet til et samfunn med plass til alle.

Videre virker det paradoksalt at par kan velge å frembringe barn som har en tilstand (bærerstatus) som de selv oppfatter som uønsket, og som de søker helsehjelp for. At bærerstatus bringes videre, behøver ikke å være noe problem for det fremtidige barnet, da det vil kunne nyte godt av samme behandling som foreldrene. Dette er derfor et tilsynelatende paradoks, hvor man avveier ønsket om å få barn mot den (begrensede) ulempen det er for det fremtidige barnet å være bærer (type 1b). I tilfeller der bærerstatus også medfører symptomer, og der symptomene kan forverres når bærerstatusen nedarves (slik som ved Fragilt-X syndrom), utfordres vi mer.

Det kan også fremstå som et paradoks at så mange fritt velger å gjennomgå PGD når det «innebærer behandling som kan være en stor fysisk og psykisk påkjenning», der det selv «med den beste ekspertise vil [...] kunne være vanskelig å lykkes med å få et friskt barn» (Ot.prp. nr. 26 (2006-2007): 39). Tar man hensyn til at mange svært sterkt ønsker seg et friskt barn, og derfor mener at den potensielle gevinsten overgår kostnadene, fremstår også dette som et tilsynelatende paradoks (type 1b).

\section{Paradokser relatert til ulik behandling av tilsynelatende like forhold}

I dag tillates ikke PGD ved «multifaktoriell arv» fordi det stilles krav til monogen eller kromosomal arvelig sykdom. Samtidig tillates PGD for kjønnsbundne sykdommer uten eksakt molekylærgenetisk diagnose. (Ot.prp. nr. 26: 53). At man må kjenne den (mono)genetiske diagnosen ved monogen og kromosomal sykdom, men ikke ved kjønnsbundet sykdom, kan virke paradoksalt. Det synes som om like tilfeller behandles ulikt. Tar man derimot hensyn til at kjønnsbundet sykdom er knyttet til kjente kromosomer (X og Y), reduseres dette til et tilsynelatende paradoks (type 1c).

Ved hjelpesøsken (PGD + HLA) er behandling og utvelgelse av embryo bare tillatt dersom sykdommen er arvelig. Dersom man har et alvorlig sykt barn som kan reddes av et fremtidig søsken, men sykdommen ikke er arvelig, er IVF med HLA (alene) ikke tillatt. Ved to like alvorlige sykdommer som kan reddes ved hjelpesøsken, er det bare det barnet som har en arvelig sykdom som tillates reddet. I begge tilfeller må IVF gjøres selv om parene er fertile. Også her virker det derfor som om like tilfeller behandles ulikt. Grunnen til dette er at man har villet unngå ett av de viktigste motargumentene mot PGD: At barn blir midler og ikke mål i seg selv. Ved hjelpesøsken for ikke-arvelig kreft risikerer man at behandlingen (IVF og donasjonen) 
gjøres bare av hensyn til det eksisterende syke barnet, mens ved arvelig sykdom må man gjøre PGD (for å unngå at det kommende barnet blir sykt), og det er derfor ikke er noen ekstra belastning å gjøre vevstyping (HLA). ${ }^{6}$

PGD skal vurderes ut fra sykdommens alvorlighetsgrad: «Dersom det finnes tilfredsstillende behandling, vil sykdommen ikke lenger anses alvorlig» (Ot.prp. nr. 26 (2006-2007): 51). Dette kan virke paradoksalt da de fleste som får en livstruende sykdom, opplever det som alvorlig, også når det finnes behandlingsmuligheter. Det gjelder særlig om behandlingen har usikker effekt og alvorlige bivirkninger. En livstruende sykdom blir ikke mindre alvorlig av muligheten for palliativ behandling. Her virker det som om like tilfeller behandles ulikt, men poenget er at behandlingsmulighetene avgjør hvorvidt konsekvensene av sykdommen blir alvorlige eller ikke.

Det er også paradoksalt at par som ellers ikke ville fått IVF av prioriteringsgrunner, får tilbud om PGD og dermed IVF. Eksempelvis kan par som har vært gjennom flere runder med IVF, men som ikke får flere muligheter prioriteringsmessig, få nye forsøk med IVF (og PGD) dersom det viser seg at én eller begge i paret er bærer av kromosomfeil. Enkelte oppfatter det som paradoksalt (og urettferdig) at de som er bærere av en arvelig sykdom eller har kromosomfeil (ubalanserte translokasjoner), får flere muligheter for IVF enn de som ikke har det. Hos de med kromosomfeil er det nettopp kromosomfeilen som gjør at de ikke får barn. De har derfor mindre sjanse for å lykkes med IVF enn andre, og kan følgelig ha krav på ekstra behandling.

\section{Tilsynelatende paradokser ved uuttalt eller mangelfull argumentasjon}

Helsetiltak begrunnes i Norge ut fra prognosetap, forventet nytte og kostnadseffektivitet (Prioriteringsforskriften, FOR 2000-12-01 nr. 1208). Det virker paradoksalt å tilby et helsetiltak som er «ressurskrevende og høyteknologisk, [som] innebærer behandling som kan være en stor fysisk og psykisk påkjenning og det kan være vanskelig å lykkes med å få et barn» (Ot.prp. nr. 26 (2006-2007): 49) uten at det er noen som er syke. Én eller begge i paret som ønsker PGD, kan være syke, men behandlingen (IVF med PGD) gjelder ikke dem. Det fremtidige barnet er ikke sykt, for det finnes ikke. Er det alternativt det befruktede egget som er sykt? Flere av de befruktede eggene vil være affisert slik at kommende barn vil kunne få sykdom-

men om de blir født. Å argumentere for at det befruktede egget er gjenstand for helsehjelp, vil kunne løse paradokset (type 1d). ${ }^{7}$

I den opprinnelige bioteknologiloven (av 2003) var PGD kun tillatt for alvorlig arvelig kjønnsbunden sykdom uten behandlingsmuligheter. Med Mehmet-saken ble det mulig for personer med barn med alvorlig arvelig sykdom å få barn som selv ikke hadde den alvorlige sykdommen, og som kunne hjelpe det allerede syke barnet (PGD + HLA, hjelpesøsken). Denne 
saken ble brukt for å etablere PGD generelt (uten HLA). I dag gis PGD i overveiende grad for at personer som har vansker med å få barn (på grunn av kromosomfeil), skal kunne få barn (Tabell 4 og www.klagenemnda.no). Det virker paradoksalt at en metode som er innført for å hjelpe alvorlig syke barn og unngå at personer med alvorlige arvelige sykdommer i familien får syke barn, i hovedsak blir brukt for å behandle ufrivillig barnløshet. Dette er et tilsynelatende paradoks hvis formålet med PGD ikke bare er å unngå å få syke barn i familier med alvorlig arvelig sykdom, men «å gjøre det mulig for par med anlegg for en alvorlig, arvelig sykdom å oppnå graviditet uten at den arvelige sykdommen blir videreført til fosteret» (Ot.prp. nr. 26: 39). Her er hensikten å oppnå graviditet med et friskt foster, og dette oppnås både når PGD gjøres for å unngå monogen arvelig sykdom, og når det gjøres ved kromosomal arvelig sykdom. Å tydeliggjøre det doble formålet med PGD løser paradokset (om man aksepterer det doble formålet).

PGD er tillatt for alvorlig sykdom. Flere av sykdommene som det gis PGD for (Tabell 4), er ikke spesielt alvorlige, og det kan derfor virke paradoksalt å kalle dem «alvorlig arvelige sykdommer». Dette paradokset har sin konkrete historiske forklaring. Mehmet-saken gjorde thalassemia major til en standard for vurdering av hva som kan regnes som «alvorlig arvelig sykdom», selv om den kan behandles med blodoverføringer og benmargstransplantasjon (fra familiær eller fremmed giver). Departementet og dispensasjons- og klagenemnda påpekte at "[s]ykdommen ß-thalassemia major er ikke den mest alvorlige sykdommen som finnes. Man kan leve til man er 40-50 år» (Ot.prp. nr. 26: 43).

Alvorlighetskravet virker også paradoksalt når man tar i betraktning at det for noen translokasjoner ikke er kjent at det er født levende barn. (Det gjelder for eksempel translokasjon 2-15 og 2-18.) Det er paradoksalt at man vurderer en tilstand som ikke har eksistert som alvorlig. Også dette er et tilsynelatende paradoks (type 1d) fordi det finnes uendelig mange translokasjoner, og fordi de kan opptre på svært mange steder på kromosomet. At tilstanden ikke er dokumentert, betyr ikke at den ikke finnes, og selv om den ennå ikke har opptrådt hos levendefødte barn, er det ut fra tilsvarende kromosomavvik grunner til å tro at tilstanden vil bli svært alvorlig dersom et barn blir født med den.

Ved alvorlig arvelig sykdom skal det, ifølge Helsedepartementet, vurderes om det er «stor fare for at et barn unnfanget på vanlig måte vil arve den aktuelle genfeilen eller kromosomanomalien» (Ot.prp. nr. 26: 51). Dersom foreldrene har samme recessive genfeil, har barnet 25 prosent sjanse for å få den aktuelle sykdommen. Det kan virke paradoksalt at det oppfattes som stor sjanse for å få et barn med genfeil når det er 75 prosent sjanse for at barnet ikke blir sykt. Dette er et tilsynelatende paradoks (type 1d) hvis man sammenligner med den implisitte argumentasjonen for fosterdiagnostikk 
for Downs syndrom (DS), hvor en sannsynlighet for å få barn med DS på 1 prosent regnes som en «stor risiko».

Ved translokasjoner og strukturelle kromosomfeil vil sannsynligheten for å føde et alvorlig sykt barn være liten fordi svangerskapet ofte ender i spontanabort på grunn av kromosomfeilen (Bioteknologinemnda 2010). For flere typer kromosomfeil som det innvilges PGD for, er sannsynligheten for at det blir født et alvorlig sykt barn godt under 1 prosent. Likevel oppfattes dette som at «det foreligger høy risiko for at et alvorlig sykt barn blir født» (Ot.prp. nr. 26 (2006-2007): 52). Det virker derfor paradoksalt at det er «[s]tor fare for at sykdommen kan overføres til et kommende barn» (Ot.prp. nr. 26: 67) når det er liten sannsynlighet for at det blir født et kommende barn. Også dette kan forstås som et tilsynelatende paradoks (type 1d) hvis PGD oppfattes som en behandling for infertilitet eller for å unngå aborter.

Departementet skriver om PGD at «behandlingen innebærer store påkjenninger så vel psykisk som fysisk», at «påliteligheten ved analysene kan være begrenset», og at «metoden er belastende for paret, ressurskrevende og ikke minst usikker med tanke på resultatet» (Ot.prp. nr. 26 (20062007): 58. Se også s. 39). Det virker paradoksalt at man setter store ressurser inn på en metode som er belastende og usikker. Også dette er et tilsynelatende paradoks (type 1d) dersom man tar hensyn til relevante, men uuttalte forklaringer: Reproduksjonsteknologiens store symbolske verdi (menneskets makt over naturen), betydningen av å få friske barn, behovet for å føre genene videre, det at vi har vanskelig for å si nei til muligheter som foreligger («mulighetenes imperativ») samt vår tiltro til moderne medisinsk teknologi («det teknologiske imperativ») (Hofmann 2002; 2009).

Det virker også paradoksalt at man gjør PGD for å unngå fosterdiagnostikk og påfølgende selektiv abort (Ot.prp. nr. 26 (2006-2007): 39), samtidig som det understrekes at «genetisk forsterdiagnostikk i løpet av svangerskapet [ofte vil] være å anbefale» (Ot.prp. nr. 26 (2006-2007): 58) ved PGD. Det kan virke som om PGD likevel ikke reduserer bruken av fosterdiagnostikk. Dette er et tilsynelatende paradoks, da det reelle (totale) behovet for selektiv abort blir vesentlig redusert ved PGD, selv om metoden ikke er 100 prosent nøyaktig. PGD-en gjøres for å sikre at embryoet ikke har en alvorlig gen- eller kromosomfeil, og fosterdiagnostikken gjøres for å kvalitetssikre PGD-en.

Et annet eksempel på denne formen for paradoks finner vi ved hjelpesøsken (PGD + HLA), der departementet påpeker at PGD gjøres «av hensyn til det kommende barnet i seg selv» (Ot.prp. nr. 26 (2006-2007): 53), slik at dette barnet kan være friskt. Dette er paradoksalt da det kan hevdes at «det kommende barnet» ikke har nytte av PGD, ettersom embryoet som er affisert, vil bli destruert og aldri bli til et barn, mens det barnet som blir født, stammer fra et «friskt» embryo og derfor ikke har hatt nytte av PGD. 
Også dette er et tilsynelatende paradoks som kan forklares ved at enkelte par ikke ville forsøke å få barn uten PGD, og ved utfordringen i å vurdere interessene til ikke-eksisterende potensielle personer (Parfit 1986). En annen underliggende forklaring er at man vil forsikre seg om at barn ved PGD + HLA ikke brukes (bare) som midler, men også som mål i seg selv. Argumentet om at det kommende barnet har nytte av PGD, brukes for å skille PGD + HLA fra tilfeller der HLA gjøres uten at det foreligger en arvelig sykdom. HLA legitimeres gjennom at det likevel skal gjøres PGD. Ved HLA (alene) gjøres IVF kun med tanke på det syke søsken: «Barnet har ikke selv nytte av å bli til ved PGD-behandling» (Ot.prp. nr. 26 (2006-2007): 57).

Som vi har sett, gjøres PGD for å unngå syke barn og spontanaborter (ved kromosomfeil) og for å øke sannsynligheten for at (friske) barn blir født. I tillegg anbefales det at det gjøres fosterdiagnostikk for å sikre seg at det kommende barnet ikke får en rekke (andre) sykdommer. Når man likevel gjør PGD, er det samtidig mulig å gjøre analyser som utelukker andre tilstander enn dem man har identifisert hos en eller begge de potensielle foreldrene. Det virker paradoksalt at dette ikke er tillatt når påfølgende fosterdiagnostikk er tillatt og anbefalt. PGD kunne her brukes til å velge bort alle affiserte embryoer, unngå spontanaborter og øke suksessraten. Dette faller inn under preimplantasjonsgenetisk screening (PGS) ${ }^{8}$ og utgjør et tilsynelatende paradoks (type 1d), da det så langt er dokumentert at PGS ikke øker antall fullførte svangerskap (Mastenbroek et al. 2008).

Dette viser at det er nære sammenhenger mellom de ulike typene tilsynelatende paradokser. Overgangene mellom begrepsmessige (språklige) uklarheter, underliggende avveiinger, manglende ulikheter og manglende argumenter er på ingen måte absolutte. I underliggende avveiinger kan det for eksempel ligge viktig (men ikke uttalt) argumentasjon. Det er også viktig å merke seg at analysen ikke sier noe om gyldigheten til de argumentene som «forklarer» og «løser» de tilsynelatende paradoksene. Konkret (opp)løsning av tilsynelatende paradokser vil i stor grad avhenge av normativt ståsted. Her er poenget snarere at løsninger faktisk finnes. Tilsvarende avhenger grensene mellom tilsynelatende paradokser og antinomier av perspektivene man har. For den som ikke aksepterer den underliggende argumentasjonen som forklarer og løser opp et tilsynelatende paradoks, fremstår de samme forholdene som en antinomi.

\section{Antinomier}

Spørsmålet om det befruktede eggets (embryoets) moralske status er kontroversielt. Dersom det befruktede egget har (full) moralsk status, vil det være drap å destruere det, men hvis det er en «celleklump», er det ikke moralsk utfordrende. Dette utgjør en antinomi som også gjelder et graduelt 
syn på moralsk status, da man fortsatt dreper noe som har (mindre) moralsk status. Embryoer og fostre regnes som nødvendige og sårbare forstadier til å bli et barn og en borger (Finnis 1973; Scott 2006) og tillegges rett til beskyttelse (Warnock 1985), eksempelvis i abortlovgiving. Ved PGD blir det spesielt tydelig hvor stor verdi ikke-affiserte embryoer har for parene det er deres mulighet til å få barn som ikke har en alvorlig arvelig sykdom. Kjernen i antinomien er motsetningen mellom prinsipper for menneskeverd eller rett til beskyttelse på den ene siden og prinsipper om reproduktiv autonomi og grunnleggende ønsker om å få friske barn på den annen.

På tross av krav om prognosetap, forventet nytte og kostnadseffektivitet (Bioteknologiloven, $\$ 2 \mathrm{~A}-4$, fjerde ledd; Prioriteringsforskriften, FOR 2000-12-01 nr.1208), gjennomføres PGD selv om effekten og kostnadseffektiviteten er lav eller ukjent. ${ }^{9}$ Dette virker paradoksalt: «PGD er en ressurskrevende behandling basert på høyteknologiske metoder. Selv med den beste ekspertise vil det kunne være vanskelig å lykkes med å få et friskt barn» (Ot.prp. nr. 26: 39), og PGD «innebærer behandling som kan være en stor fysisk og psykisk påkjenning og det kan være vanskelig å lykkes med å få et barn» (Ot.prp. nr. 26 (2006-2007): 49). I henhold til prioriteringsforskriften (FOR 2000-12-01 nr. 1208) har bæreren ikke noe prognosetap ved at PGD ikke utføres, og har følgelig ikke rett til nødvendig helsehjelp. Dessuten eksisterer det ikke noen pasient: «Når det gjelder PGD for å utelukke alvorlig, arvelig sykdom hos det kommende barn, foreligger det ingen pasient» (Ot.prp. nr. 26 (2006-2007): 62). I tillegg er kostnadseffektiviteten ukjent. Dette fremstår som en antinomi der prinsippene for prioritering (prognosetap, effekt og kostnadseffektivitet og derigjennom rettferdighetsprinsippet) står mot hjelpeplikten.

Det virker også paradoksalt at risiko for sykdom selv gjøres til sykdom ved å bli gjenstand for behandling, for eksempel ved at (a) PGD gjøres for å minske risikoen for å få et sykt barn, (b) PGD gjøres for tilstander som lar seg behandle, men der det er risiko ved behandlingen (eksempelvis betathalassemi), og (c) der det gjøres PGD + HLA for tilstander der sykt barn er behandlet for en gitt type sykdom, men der behandlingen bare er delvis vellykket og barnet kan komme til å trenge ny behandling i fremtiden. Risiko for sykdom (og bærerstatus) mangler vanlige kriterier for sykdom, slik som smerte, ubehag, lidelse, redusert funksjonsevne etc. Dersom risiko for sykdom oppfattes som prinsipielt forskjellig fra manifest sykdom, utgjør dette en antinomi.

I tillegg skjuler formuleringen om at bærerstatus skal unngås (Ot.prp. nr. 26 (2006-2007): 52, se ovenfor) en antinomi, da den uttrykker et ønske om å unngå «dårlige gener» (eugenikk): Det grunnleggende prinsippet om at alle (også potensielle personer) har lik verdi, står da mot prinsippet om at man skal bidra til helse og unngå sykdom. 
I de norske forarbeidene oppfattes embryoet både som gjenstand for helsehjelp og ikke som gjenstand for helsehjelp ved at det oppfattes som «avkom», og ved at det ikke foreligger noen pasient (Ot.prp. nr. 26 (20062007): 62). Paradokset oppstår når embryoet og fosteret tillegges moralsk status som «avkom»: Fordi det er risiko «for at sykdommen overføres til parets avkom, enten det dør i livmoren eller blir født med en alvorlig sykdom», så kan det gjøres PGD. Å tillegge embryo og foster samme status som et (sykt) barn virker paradoksalt og strider mot oppfatningene som ligger til grunn for annen lovgiving (eksempelvis abortloven). Dette kan derfor forstås som en antinomi. Dessuten er det paradoksalt at embryo og fostre som ikke vil kunne utvikle seg til levende barn (fordi de vil spontanaborteres), omtales som «avkom».

For å unngå paradokser har man forsøkt å samstemme kriteriene for «alvorlig arvelig sykdom» ved senabort og ved PGD (Ot.prp. nr. 64 (20022003)). I begge tilfeller gjøres alvorlighetsvurderingen i forhold til belastningen som tilstanden vil utgjøre for de kommende foreldrene og for det potensielle barnet. Forskjellene er at vurderingene ved PGD gjøres før unnfangelsen, mens det ved senabort gjøres når fosteret finnes. I tillegg er hensikten forskjellig, da den ved PGD er å frembringe et barn uten en gitt alvorlig sykdom, mens den ved senabort er å forhindre fødsel av et barn med alvorlig sykdom (Harris 1998). Forsøket på å samordne oppfatningene av «alvorlig arvelig sykdom» ved senabort og PGD kan derfor likevel være paradoksalt dersom man mener at det er forskjell i retten på beskyttelse for embryo og fostre, eksempelvis ut fra et graduelt syn på moralsk status (Scott 2006), og dersom man mener at det er moralsk relevant forskjell på intensjon og skapelsesbeslutning (Solberg 2010) i de to tilfellene. I slike perspektiv vil det være en antinomi der prinsippet om at fostre har rett til beskyttelse, vil stå mot prinsippet om at embryo ikke har moralsk status, eller at intensjonene ved PGD og abort er vesensforskjellige.

Som vi har sett, er det paradoksalt at sykdommene som det tillates PGD for, ikke alle oppfattes som alvorlige. ${ }^{10}$ Dette kan fremstå som en antinomi dersom man legger vekt på at de potensielle foreldrene og det potensielle barnet har ulike og til dels motstridende interesser. Empiriske studier viser at alvorlighetsgraden vurderes ulikt av mennesker med en gitt sykdom og deres foreldre (Murray 1996; Scott 2003). Da vil prinsippene for vurdering av alvorlighetsgrad hos foreldre og «barnets beste» stå mot hverandre, og utfordringen ligger i det faktum at det potensielle barnet aldri vil kunne gjøre sine (tilblivelsesrelaterte) interesser gjeldende.

Det samme skjer når prinsipper om valgfrihet og selvbestemmelse står mot sterke føringer for slike valg. PGD gir personer med arvelig sykdom i familien økte reproduktive valg (Robertson 1994; 2003; Harris 2006; 2007). Det er enklere å velge å få barn når risikoen for å få syke barn minsker, og PGD gjør det mulig å unngå spontanaborter (ved kromosomfeil), slik at par 
som ellers ville ha vansker med å få barn, kan få det. PGD gjør det mulig å gå fra skjebne og sjanse til bevisste valg (Buchanan et al. 2000). Derfor virker det paradoksalt dersom pars økte valgmuligheter i praksis reduserer deres valgfrihet. I andre land føler (særlig kvinner) at de ikke har noe valg annet enn å gjennomgå PGD (Krahn \& Wong 2009) på tross av at de informeres både om adopsjon og sæddonasjon. Kvinner som verken er syke eller er bærere av sykdom, føler at PGD er «det eneste rette valget» (Zeiler 2004), og at familierelasjoner kan gi uformelt press (Ho 2008). Her står autonomi mot heteronomi i en antinomi. Det samme gjelder når idealer og holdninger i samfunnet virker førende på kvinnene (Krahn \& Wong 2009; Lippman 1999), eksempelvis når liberalistiske og feministiske oppfatninger står mot hverandre og individualistisk selvbestemmelse står mot relasjonell autonomi (Krahn \& Wong 2009).

Der det settes inn befruktede egg med bærerstatus eller premutasjoner, vet helsepersonell og de fremtidige foreldrene noe om den genetiske (sykdoms)statusen til det kommende barnet. Her står ønsket om å få et barn mot retten til en åpen fremtid (Habermas 2003) og retten til privatliv. Personen mangler kontroll over hvem som har kunnskap om vedkommendes helsestatus og eventuelle behov for helsehjelp. Dersom disse verdiene ikke lar seg forene eller avstemme, har vi en antinomi. I tillegg virker det paradoksalt at genetisk kunnskap fremkommer og forutsettes kjent for barn ved PGD, mens genetiske undersøkelser av barn for å fremskaffe tilsvarende informasjon er forbudt (Bioteknologiloven $₫ 5-7$ ). Her står prinsippet om retten til ikke å vite mot det faktum at kunnskap er nødvendig for å gjøre PGD.

Noen av paradoksene (antinomiene) skyldes en dobbel målsetting: PGD brukes for å hindre at par med anlegg for en alvorlig arvelig sykdom skal føre denne videre til et fremtidig barn. I tillegg brukes PGD for å sikre at det blir født et friskt barn, eksempelvis ved kromosomfeil. Det å ha flere målsettinger med en helsetjeneste skulle i utgangspunktet ikke være problematisk, men det er når slike målsettinger kommer i konflikt med hverandre, eller at det er uenighet om dem, at det oppstår antinomier.

Flere av antinomiene fremkommer av konflikter mellom prinsipper, interesser og perspektiver. I Norge har dette vært særlig tydelig i debatten dominert av et liberalt og et restriktivt syn (Utskarpen \& Foss 2009).

\section{Aporier}

Mens det er forholdsvis enkelt å påvise tilsynelatende paradokser og antinomier, kan det være vanskeligere å identifisere aporier. Dette skyldes at selv antinomier kan la seg løse, eksempelvis ved at ny teknologi, slik som omprogrammering av kroppsceller til kjønnsceller, eller ny kunnskap om 
embryoenes utvikling, gjør det mulig å tilfredsstille begge syn, eller at helt nye perspektiver bringes inn.

Enn så lenge synes spørsmålet om embryoets og fosterets rett til beskyttelse å utgjøre en apori. Her har grunnleggende prinsipper stått mot hverandre over lang tid. Det kan være vanskelig å løse denne typen kontroverser ved hjelp av kompromisser fordi etiske konflikter ofte handler om dypt motstridende perspektiver som det er vanskelig å gi slipp på (Nelkin 1995). Svaret på spørsmålet om fosterets moralske status henter dessuten ofte premisser fra metafysikken (som ikke enkelt lar seg begrunne). For å sitere Hug og Hermerén: «The ethical positions concerning the use of human embryos for research purposes are controversial $[\ldots]$ and there is no possibility of [...] compromising this disagreement» (Hug 2011: 205).

Dette antyder at spørsmålet om fosterets moralske status og rett på beskyttelse synes å være en apori.

\section{Diskusjon}

Denne artikkelen har identifisert en rekke tilsynelatende paradokser på PGD-ens område. At PGD gjøres selv om det er svært liten sannsynlighet for at det blir født et alvorlig sykt barn, og at det gjøres PGD for mindre alvorlige sykdommer når forutsetningen for PGD er alvorlig arvelig sykdom, er eksempler på dette. Samtidig finnes det også antinomier: At PGD gir rett på helsehjelp når PGD har høye kostnader og lav suksessrate og uten at det eksisterer noen pasient, er eksempler. Da det er vanskelig å spå hvilke antinomier som er så bestandige at de utgjør aporier, er det identifisert få aporier, men fosterets moralske status (og dets rett på beskyttelse) er en klar kandidat.

At man kan identifisere en rekke paradokser på PGD-ens område, er ikke overraskende. PGD har vært gjenstand for betydelig debatt, der sterke oppfatninger og interesser står mot hverandre. Det er langt mellom de enkle løsningene, og politiske og moralske kompromisser har vært nødvendige for å regulere PGD. Samtidig gjør kompleksiteten ved PGD at moralske standpunkt strategisk maskeres i en vitenskapsorientert retorikk. Det gjør at tekniske detaljer (eksempelvis om embryoets utvikling og genetiske avvik) overskygger verdispørsmål (Nelkin 1995: 449-453). I slike tilfeller kan paradoksanalyser være klargjørende ved at de kan synliggjøre underliggende verdikonflikter.

Analysen viser at omfanget av tilsynelatende paradokser er stort. Dette kan skyldes at man innenfor genetisk testing og assistert reproduksjon vet at det finnes en rekke grunnleggende utfordringer, og at man må regne med inkonsistens og derfor er mindre kritisk til paradokser. Det motsatte kunne like gjerne være tilfellet: Fordi det er et kontroversielt tema med motstri- 
dende prinsipper og interesser, skulle det være særdeles viktig å rydde unna tilsynelatende paradokser.

Det er mange flere paradokser ved PGD enn dem som har fătt plass i denne artikkelen. Det er åpenbare muligheter for at utvalget av forhold som er beskrevet som paradokser, er skjevt, og at klassifiseringen av paradoksene er avhengig av ståsted og oppfatning. Her kan den kritiske leser gå meg etter i sømmene. Poenget med paradoksanalysen er at den kan klargjøre debatten og peke på muligheter og begrensninger for å finne løsninger og oppnå konsensus.

Det er ikke nødvendigvis slik at analysen gjennom paradokser kan belyse alle moralske utfordringer med PGD. En grunn til at paradoksanalysen likevel kan være nyttig, er at moralske dilemma nettopp er karakterisert av motsetninger (di-lemma), som er så typiske for paradokser.

Analysen viser også at de samme forholdene kan fremkalle paradokser av forskjellige slag. Slike «ansamlinger av paradokser» kan selvsagt skyldes ulike tolkninger av samme situasjon, men de kan også bety at situasjonen er kompleks der mange argumenter, prinsipper, verdier og interesser gjør seg gjeldende. Slike paradoksansamlinger er derfor spesielt interessante å undersøke. I tillegg er det makt i paradoksenes kategorier: Å kategorisere noe som en apori indikerer at man lite kan gjøre, mens å kalle noe for et tilsynelatende paradoks eller en antinomi antyder at det lar seg (opp)løse. Det kan også få normative implikasjoner som at et tilsynelatende paradoks ikke er viktig eller alvorlig, men slik er det selvsagt ikke: At noe er et tilsynelatende paradoks, sier bare at det lar seg løse, og ikke hvorvidt det er riktig, viktig eller har alvorlige implikasjoner.

Ett eksempel kan illustrere at også tilsynelatende paradokser er viktige: Det er et paradoks at vi bruker så mye ressurser på å forsøke å bringe friske barn til verden med en så lite effektiv metode, når de samme ressursene kunne ha reddet mange barn som hvert sekund dør av sykdommer som enkelt kan forebygges og behandles med effektive midler, eller at barna mangler omsorgspersoner. Dette er et tilsynelatende paradoks fordi det kan forklares av konkrete maktforhold i verden, og ved at en reduksjon i PGD hos oss ikke direkte redder barn i andre land. Selv om dette er et tilsynelatende paradoks, representerer det en av de viktigste moralske utfordringene i vår tid. Eksemplet viser også at paradoksanalysen er kontekstuell. Den gir kun mening innenfor den typen helsevesen som vi har i den (nord)vestlige verden. En globalt anlagt paradoksanalyse vil se ganske annerledes ut.

Som allerede antydet er paradoksanalysen lite egnet i ytterkantene av det normative landskapet (eksempelvis for «konservativ deontologi» eller «radikal teleologi»). Den egner seg best til å klargjøre motsetninger i et mer nyansert normativt terreng. Hva leder så paradoksanalysen til? Hva kan vi gjøre? Analysen viser at mange av paradoksene lar seg løse eller forklare. Det betyr at mer informasjon og opplysning kan vise at mange av motset- 
ningene bare er tilsynelatende. På den måten kan skinnuenighet ryddes av veien, og man kan konsentrere seg om de harde utfordringene. Tilsvarende er det viktig å konsentrere seg om å finne mulige løsninger for motstående prinsipper (verdier, teorier og posisjoner) ved antinomiene. Det kan gjøres ved å finne overbevisende argumenter som viser at noen av prinsippene er mer gyldige enn andre. Det kan også gjøres ved å finne nye perspektiver som gjør det mulig å håndtere de ulike interessene og hensynene på en god måte, og som løser opp motsetningene mellom eksisterende prinsipper. Analysen kan også bidra til å redusere ambisjonene om å løse aporiene. Vi må selvsagt ikke la være å forsøke å finne embryoets og fosterets moralske status, men det kan være uhensiktsmessig å gjøre det til en forutsetning for konkrete måter å regulere PGD på. Både å løse opp de tilsynelatende paradoksene, å forsøke å finne løsninger på antinomiene og å respektere aporiene er viktige oppgaver i forbindelse med den forestående vurderingen og revisjonen av bioteknologiloven.

\section{Konklusjon}

Denne artikkelen har analysert en rekke av de paradoksene som fremkommer i den norske reguleringen av preimplantasjonsgenetisk diagnostikk (PGD). Noen av disse er tilsynelatende paradokser som lar seg forklare og løse. Andre er antinomier der grunnleggende prinsipper står mot hverandre. En tredje type paradokser er aporier der vi står overfor tilsynelatende uløselige motsetninger.

Ekstreme posisjoner gir få paradokser fordi man kun forholder seg til ett perspektiv eller ett (sett av) prinsipp(er), det være seg i liberal eller restriktiv støpning. Prøver man å balansere grunnleggende (og ikke-forenlige) perspektiver, slik man gjør i regulering av reproduksjonsteknologi i Norge, vil man oppleve motsetninger mellom prinsipper. Det gir moralske utfordringer som kan studeres som paradokser.

Å formulere moralske utfordringer som paradokser kan være en fruktbar fremgangsmåte for å tydeliggjøre motsetninger og konkrete utfordringer. Dessuten kan det styre innsatsen: Vi bør bestrebe oss på å rydde opp i tilsynelatende paradokser, jobbe hardere med grunnlagsutfordringene ved antinomier og til en viss grad akseptere utfordringene med aporiene.

\section{Interessekonflikter}

Bjørn Hofmann er medlem av PGD-nemnda. All informasjon i denne artikkelen er hentet fra offentlig tilgjengelige kilder, og analysen eller vurderingene er forfatterens egne og er ikke uttrykk for PGD-nemndas syn. 


\section{Noter}

1 Betegnelsen hjelpesøsken («savior sibling») brukes om barn som blir til ved hjelp av genetisk undersøkelse av embryo. Hensikten er å frembringe søsken som kan være donor for et allerede sykt barn. Den genetiske undersøkelsen av embryoet skal da sikre at det fremtidige barnet ikke får samme sykdom som det allerede syke barnet, samtidig som det har en vevstype (HLA) som gjør det egnet som donor.

2 Med prinsipp menes her normer for rett og galt som et individ eller en gruppe har, og som anses som handlingsveiledende.

3 I Norge brukes også betegnelsen preimplantasjonsdiagnostikk, for eksempel i Ot.prp. nr. 26 (2006-2007). I denne artikkelen brukes betegnelsen preimplantasjonsgenetisk diagnostikk (PGD) i tråd med den engelske betegnelsen for å synliggjøre den genetiske undersøkelsen.

4 Tilsvarende paradoks finner vi når røntgenundersøkelser og laboratorietester tas for å berolige pasienten, eller for å dempe legers angst for juridiske følger (Hofmann 2005; Hofmann 2010). Det er liten tvil om at diagnostikk kan ha anxiolyttisk effekt, men så lenge denne effekten ikke er dokumentert, fremstår det som et paradoks å bruke undersøkelser som terapi.

5 Spørsmålet om hva sykdom er rommer en rekke paradokser (Hofmann 2008a). Her drøftes bare hvorvidt bærerstatus og risiko for er sykdom.

6 Dette er en gjengivelse av argumentet i debatten i 2004 og ikke en vurdering av om argumentet er holdbart. Se også senere, under tilsynelatende paradokser ved uuttalt eller manglende argumentasjon.

7 Dette strider mot annen lovgiving, eksempelvis abortloven. Se også senere.

8 PGS er ikke tillatt i Norge i dag.

9 Sannsynligheten for å lykkes med å få et friskt barn er i størrelsesorden 10 prosent (Basille 2009). Suksessraten er oppgitt å være noe høyere for PGD og noe lavere for PGD + HLA. Ot.prp. nr. 26 angir 16 prosent «take home baby rate» basert på ESHRE data. Nyere ESHRE data oppgir klinisk graviditet på 19 prosent per oocyte retrieval (OR) og 26 prosent per embryo transfer (ET) for PGD og henholdsvis på 21 prosent og 34 prosent for translokasjoner, men ikke «take home baby rate» (Harper 2010). På ESHREs konferanse i Stockholm 3.-6. juli 2011 presenterte G. Harton oppdaterte tall til og med 2009, der tallene for PGD samlet sett var på 22 prosent (per OR) og 28 prosent (per ET) for PGD og 18 prosent (per OR) og 28 prosent (per ET) for kromosmoavvik, men heller ikke her ble tall for «take home baby rate» presentert. Det er ikke dokumentert fødte hjelpesøsken som har reddet sine søsken i Norge.

10 Det gjøres PGD for sykdommer som kan ha svært milde uttrykk (eksempelvis nevrofibromatose, type 1). Dette kan oppfattes som et tilsynelatende paradoks dersom man ikke vet om det blir en mild eller mer alvorlig form, og dersom risiko for sykdom oppfattes som sykdom. Ellers vil det være en antinomi der det formelle kravet om alvorlig sykdom står i strid med den praktiske normen mild sykdom.

\section{Litteratur}

Angeles, L. (2009) Children and life satisfaction. Journal of Happiness Studies, 11 (4), s. 523-538.

Baruch, D. \& Kaufman K.L. (2008) Hudson. Genetic testing of embryos: practices and perspectives of US IVF clinics. Fertil Steril, 89, s. 1053-1058. 
Basille, C., Frydman, R., El Aly, A., Hesters, L., Fanchin, R., Tachdjian, G., Steffann, J., LeLorc'h, M. \& Achour-Frydman, N. (2009) Preimplantation genetic diagnosis: state of the art. European Journal of Obstetrics \& Gynecology and Reproductive Biology, 145 (1), s. 9-13.

Bioteknologinemnda (2010) Preimplantasjonsdiagnostikk PGD. Oslo: Bioteknologinemnda.

Bjørvik, E. (2009) Mot tidligere ultralyd. Bergens Tidende, 17.7.2009.

Buchanan, A.E., Brock, D.W., Daniels, N. \& Wikler, D. (2000) From chance to choice: Genetics and Justice. Cambridge UK: Cambridge University Press.

Finnis, J. (1973) The Rights and Wrongs of Abortion: A Reply to Judith Thomson Philosophy \& Public Affairs, 2 (2), s. 117-145.

Folge, L. (2006) Mehmet-saken - en seier for pressen? Tidsskrift for Den Norske Loegeforening, 126, s. 876.

Glover J. (1984) What Sort of People Should There Be? Harmondsworth: Penguin, s. 31-32.

Habermas, J. (2003) The Future of Human Nature. Oxford: Polity Press.

Hafstad, A. (2004) Folk mer åpne enn politikerne for bioteknologi. Aftenposten, 20.12.2004.

Harper, J.C., Coonen, E., De Rycke, M., Harton, G., Moutou, C., Pehlivan, T., Traeger-Synodinos, J., Van Rij, M.C. \& Goossens, V. (2010) ESHRE PGD Consortium data collection X: cycles from January to December 2007 with pregnancy follow-up to October 2008. Human Reproduction, 25 (11), s. 26852707. Epub 2010 Sep 2.

Harris, J. (1998) Rights and Reproductive Choice. I The Future of Human Reproduction: Ethics, Choice and Regulation, red. J. Harris \& S. Holm, s. 32-33. Oxford: Oxford University Press, 5.

Harris, J. (2006) The moral choice: prospective mothers should have the right to select embryos on the basis of knowing as much as possible about their future health. New Scientist 190 (2556), s. 24.

Harris, J. (2007) Enhancing evolution: The ethical case for making better people. Princeton NJ: Princeton University Press.

Haug, C. (2005) Ingen skam og snu. Tidsskrift for Den Norske Logeforening, 125, s. 413.

Haug, C. (2006) Optimisme og realisme i etisk grenseland. Tidsskrift for Den Norske Logeforening, 126, s. 1193.

Haug, K. (2006) Ut mot biotek-liberalisering. Klassekampen, 9.11.2006.

Helsedirektoratet (2010) Bioteknologilovens etiske problemstillinger. Lastet ned 20. desember 2010 fra http://www.helsedirektoratet.no/bio_genteknologi/ fagnytt/bioteknologilovens_etiske_problemstillinger_749504

Ho, A. (2008) Relational autonomy or undue pressure? Family's role in medical decision-making. Scandinavian Journal of Caring Sciences, 22 (1), s. 128-135.

Hofmann, B. (2001) Complexity of the concept of disease as shown through rival theoretical frameworks. Theoretical Medicine and Bioethics, 22 (3), s. 211-237.

Hofmann, B. (2001) The paradox of health care. Health Care Analysis, 9: s. 369-386.

Hofmann, B. (2002) Is there a technological imperative in health care? International Journal of Technology Assessment in Health Care, 18 (3), s. 675-689.

Hofmann, B. (2004) Kampen om bioteknologiloven. Aftenposten, 1.8.2004.

Hofmann, B. (2005) For sikkerhets skyld - om skylden i vår søken etter sikkerhet. Bibliotek for Loeger, 197 (4), s. 353-364. 
Hofmann, B. (2008a) Hva er sykdom? Oslo: Gyldendal Akademisk.

Hofmann, B. (2008b) Selektive utfordringer ved assistert befruktning for personer med Klinefelter syndrom. Etikk i praksis, 2 (1), s. 69-85.

Hofmann, B. (2009) Fallacies in the arguments for new technology: the case of proton therapy. Journal of Medical Ethics, 35, s. 684-687.

Hofmann, B. (2010) Too much of a good thing is wonderful? A conceptual analysis of excessive examinations and diagnostic futility in diagnostic radiology. Medicine, Health Care and Philosophy, 13 (2), s. 139-148.

Hug, K. \& Hermerén, G. (red.) (2011) Translational stem cell research. Issues beyond the debate on the moral status of the human embryo. London: Springer.

Krahn, T. \& Wong, S.I. (2009) Preimplantation genetic diagnosis and reproductive autonomy. Reproductive BioMedicine Online, 19, Suppl 2, s. 34-42.

Lippman, A. (1999) Choice as a risk to women's health. Health, Risk und Society, 1, s. 281-291.

Mastenbroek, S., Scriven, P., Twisk, M., Viville, S., Van der Veen, F. \& Repping, S. (2008) What next for preimplantation genetic screening? More randomized controlled trials needed? Human Reproduction, 23 (12), s. 2626-2628.

Murray, T. (1996) The Worth of a Child. Berkeley: University of California Press.

Nelkin, D. (1995) Science controversies. The Dynamics of Public Disputes in the United States. I Handbook of Science and Technology Studies, red. S. Jasanoff, G.E. Markle, J.C. Petersen \& T. Pinch, s. 444-457. London: Sage Publications.

Parfit, D. (1986) Reasons and Persons. Oxford: Oxford University Press.

Robertson, J.A. (1994) Children of Choice; Freedom of the New Reproductive Technologies. Princeton NJ: Princeton University Press.

Robertson, J.A. (2003) Extending preimplantalion genetic diagnosis: the ethical debate, Ethical issues in new uses of preimplantation genetic diagnosis. Human Reproduction, 18, s. 465-471.

Scott, R. (2003) Prenatal Screening, Autonomy and Reasons: the Relationship between the Law of Abortion and Wrongful Birth. Medical Law Review, 11 (3), s. 265-325.

Scott, R. (2006) Choosing between Possible Lives: Legal and Ethical Issues in Preimplantation Genetic Diagnosis. Oxford Journal of Legal Studies, 26 (1), s. 153-178.

Solberg, B. (2005) The Concept of Selection: When Are You Selecting? Is it Discriminatory? I PGD and Embryo Selection, Report from an International Conference on Preimplantation Genetic Diagnosis and Embryo Selection, red. Nordic Committee on Bioethics. Copenhagen: TemaNord/Nordic Council of Ministers.

Solberg, B. (2010) Hun er deres forelder. Aftenposten, 13.10.2010.

Utskarpen, A. \& Foss, G. (2009) PGD viss ein sjølv ikkje vil vite? Genialt, 4, s. 8-9.

Warnock Report. (1985) Report of the Committee of Inquiry into Fertilisation and Embryology, republished as A Question of Life. (Cmnd 9314). Oxford: Blackwell, 1985.

Zeiler, K. (2004). Reproductive autonomous choice - a cherished illusion? Reproductive autonomy examined in the context of preimplantation genetic diagnosis. Medicine Health Care and Philosophy, 7, s. 175-183. 